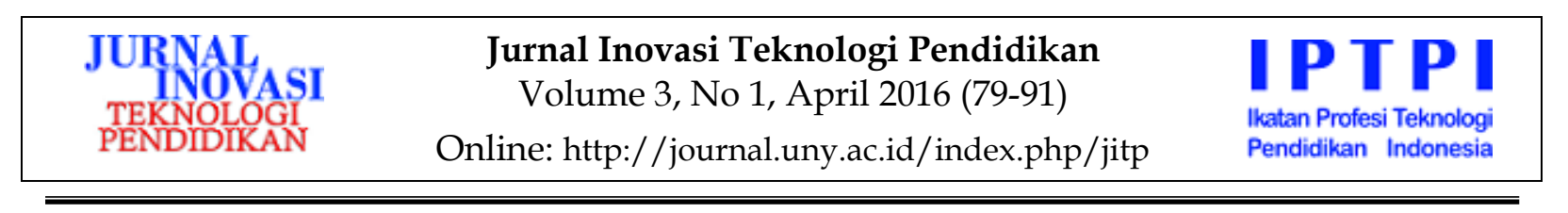

\title{
PENGEMBANGAN MEDIA PEMBELAJARAN \\ BERBANTUAN KOMPUTER DAN KEEFEKTIFANNYA TERHADAP KEMANDIRIAN BELAJAR DAN PENGUASAAN KONSEP BRYOPHYTE
}

\author{
Sri Wahyuni, Djukri \\ Balai Pengembangan Media Radio Pendidikan, FMIPA Universitas Negeri Yogyakarta \\ sriwahyuni_sw88@yahoo.com
}

\begin{abstract}
Abstrak
Penelitian ini bertujuan untuk mengetahui: (1) kelayakan media pembelajaran berbantuan komputer pada materi Bryophythe untuk peserta didik kelas X, (2) keefektifan media pembelajaran berbantuan komputer terhadap kemandirian belajar peserta didik kelas X SMA Negeri I Girimulyo, dan 3) keefektifan media pembelajaran berbantuan komputer terhadap penguasaan konsep peserta didik kelas X SMA Negeri I Girimulyo. Jenis penelitian ini adalah Research and Development (R\&D). Pengembangan dilakukan dengan mengacu pada model 4-D yang meliputi define (pendefinisian), design (perancangan), develop (pengembangan) and disseminate (penyebaran). Hasil penelitian menunjukkan bahwa: (1) media pembelajaran berbantuan komputer yang dikembangkan menurut ahli materi, ahli media, pendidik biologi, teman sejawat, peserta didik uji coba terbatas maupun peserta didik uji coba lapangan secara umum berkategori baik. Hasil tersebut menunjukkan bahwa produk pengembangan media pembelajaran biologi berbantuan komputer yang telah dikembangkan layak digunakan, (2) media pembelajaran komputer ini efektif untuk meningkatkan kemandirian belajar peserta didik, dan (3) media pembelajaran komputer ini efektif untuk meningkatkan penguasaan konsep peserta didik.
\end{abstract}

Kata kunci: media pembelajaran berbantuan komputer, kemandirian belajar, penguasaan konsep

\section{DEVELOPING COMPUTER-ASSISTED LEARNING MEDIA AND EFFECTIVENESS AUTONOMY LEARNING AND CONCEPT MASTERY BRYOPHYTE}

\author{
Sri Wahyuni, Djukri \\ Balai Pengembangan Media Radio Pendidikan, FMIPA Universitas Negeri Yogyakarta \\ sriwahyuni_sw88@yahoo.com
}

\begin{abstract}
This study aims to find out: (1) the feasibility of the computer-assisted learning media for grade $X$ students of senior high school, (2) the effectiveness of the computer-assisted learning media to autonomy learning of grade X students of SMA Negeri I Girimulyo, and 3) the effectiveness of the computer-assisted learning media to concept mastery of grade X students of SMA Negeri I Girimulyo. The type of this study was Research and Development ( $R$ ED). The development was done by referring to 4-D model including define, design, develop and disseminate. The result of the study showed that: 1) the computer-based learning media was developed according to the material expert, media expert, biology teachers, colleagues, definite testing students and field testing students which generally in good category; it showed that the computer-based learning media product that had been developed is ready to use, (2) this computer-assisted learning media effective to improve autonomy learning of learners, and (3) this computer-assisted learning media effective to improve concept mastery of learners.
\end{abstract}

Keywords: computer-assisted learning media, autonomy learning, concept mastery. 


\section{Pendahuluan}

Proses pembelajaran dapat berlangsung secara lancar, terarah, dan sesuai dengan tujuan pembelajaran, jika proses pembelajaran dapat diselenggarakan secara efektif. Menurut Hamalik (2005, p.171), pembelajaran yang efektif adalah pembelajaran yang menyediakan kesempatan kepada peserta didik untuk belajar mandiri, sehingga dengan melakukan aktivitas belajarnya peserta didik mampu memperoleh pengetahuan dari pemahaman sendiri. Jadi, pembelajaran efektif adalah pembelajaran yang mampu mengembangkan konsep generalisasi serta bahan abstrak menjadi jelas dan nyata, mampu melayani perkembangan belajar peserta didik yang berbeda-beda, melibatkan peserta didik secara aktif, dan menyediakan kesempatan kepada peserta didik untuk belajar mandiri.

Kemandirian belajar peserta didik sangat diperlukan dalam konteks belajar dan pembelajaran di kelas. Menurut Yamin (2007, p.115), belajar mandiri adalah cara belajar aktif dan partisipatif untuk mengembangkan diri masing-masing individu yang tidak terikat dengan kehadiran guru, dosen, pertemuan tatap muka di kelas, maupun kehadiran teman sekolah.

Belajar mandiri merupakan belajar dalam mengembangkan diri, keterampilan dengan cara tersendiri. Belajar mandiri hendaknya diterapkan pada semua mata pelajaran agar proses pembelajaran dapat diselenggarakan secara efektif termasuk dalam pembelajaran biologi.

Pembelajaran biologi harus dimulai dengan menghadapkan peserta didik kepada masalah-masalah nyata yang dapat diterapkan dalam kehidupannya, sehingga peserta didik diharapkan dapat memperoleh pengetahuan dan menguasai konsep biologi dengan lebih mendalam. Kenyataannya tidak semua objek dan gejala-gejala alam dapat dihadirkan dalam pembelajaran di kelas dan sulit dipelajari langsung karena terkendala dalam beberapa hal, misalnya waktu, peralatan, tenaga, dan tempat.
Hal ini dapat ditanggulangi dengan menyiapkan pengalaman pengganti yang berupa simulasi pengalaman nyata yang disesuaikan dengan karakter materi ajar.

Salah satu materi biologi yang mengalami kendala dalam pengamatan langsung adalah materi Bryophyte. Salah satu materi yang diajarkan yaitu siklus hidup tumbuhan lumut (pergiliran generasi haploid dan diploid). Siklus hidup tumbuhan lumut merupakan hal yang abstrak dan sulit diobservasi secara langsung. Dengan mengetahui sifat materi yang demikian maka tidak memungkinkan bagi peserta didik mempelajarinya hanya dengan melihat gambar saja. Penggunaan charta dalam pembelajaran tidak memungkinkan untuk dibawa pulang dan di rumah peserta didik kurang berminat jika hanya membaca buku.

Berdasar hasil observasi dan wawancara terbatas dengan guru biologi SMA N 1 Girimulyo dapat disimpulkan bahwa permasalahan utama dalam pembelajaran materi Bryophyte adalah: (1) dalam pembelajaran sebagian besar peserta didik bersifat pasif, (2) kemandirian peserta didik dalam usaha menguasai materi masih rendah, dan (3) laboratorium komputer di sekolah yang memadahi belum digunakan dan dimanfaatkan secara optimal sebagai media pembelajaran biologi terutama materi Bryophyte, (4) media pembelajaran biologi untuk materi Bryophyte belum dikembangkan.

Salah satu alternatif yang dapat digunakan untuk menanggulangi permasalahan yang terjadi di SMA I Girimulyo materi Bryophyte adalah media berbantuan komputer. Wagiran (2008, p.229), menyatakan pengembangan perangkat lunak pembelajaran berbantuan komputer dipandang layak dan penting dilakukan karena memberikan efek yang besar kepada peserta didik dalam meningkatkan kualitas pembelajaran, motivasi belajar, dan mendukung pembelajaran individual.

Salah satu software yang dapat digunakan dalam pembuatan media berbantuan komputer adalah lectora. Lectora di- 
gunakan untuk mengembangkan konten digital materi ajar dan materi uji berbentuk multimedia dinamis, mudah digunakan (user friendly) dan berkualitas tanpa membutuhkan keahlian desain seni dan grafis serta pemrograman yang tinggi untuk mengikuti dinamika perubahan sistem belajar mengajar. Software ini memiliki kemudahan dalam penyusunannya karena tidak diperlukan layer-layer yang rumit sehingga mempersingkat penyusunan media pembelajaran.

Salah satu tujuan pengembangan media pembelajaran dengan menggunakan software lectora adalah mengatasi keterbatasan daya indera baik peserta didik maupun guru. Dengan menggunakan software lectora, diharapkan siklus hidup tumbuhan lumut (pergiliran generasi haploid dan diploid) yang merupakan hal abstrak dan sulit diobservasi secara langsung karena objeknya yang kecil dapat teramati dengan menggunakan gambar, animasi, dan video sehingga penguasaan konsep peserta didik pada materi Bryophyte dapat meningkat.

Peserta didik juga dapat mempelajarinya dimana saja, dan kapan saja karena dapat digunakan secara offline, sehingga peserta didik dapat belajar secara mandiri. Pada akhirnya diharapkan media belajar berbantuan komputer yang dikembangkan ini dapat dijadikan sebagai alternatif media belajar bagi peserta didik yang berguna untuk meningkatkan kemandirian belajar dan penguasaan konsep peserta didik.

Permasalahan dalam penelitian ini adalah apakah media pembelajaran berbantuan komputer materi Bryophyte yang dikembangkan layak digunakan untuk pembelajaran bagi peserta didik kelas $X$ SMA Negeri I Girimulyo? Apakah media pembelajaran berbantuan komputer materi Bryophyte efektif terhadap kemandirian belajar peserta didik kelas X SMA Negeri I Girimulyo? Apakah media pembelajaran berbantuan komputer materi Bryophyte efektif terhadap penguasaan konsep peserta didik kelas X SMA Negeri I Girimulyo?
Tujuan penelitian ini adalah untuk mengetahui kelayakan media pembelajaran berbantuan komputer materi Bryophyte untuk peserta didik kelas X SMA Negeri I Girimulyo yang dihasilkan dalam penelitian ini. Keefektifan media pembelajaran berbantuan komputer materi Bryophyte terhadap kemandirian belajar peserta didik kelas X SMA Negeri I Girimulyo. Keefektifan media pembelajaran berbantuan komputer materi Bryophyte terhadap penguasaan konsep Peserta didik kelas X SMA Negeri I Girimulyo.

\section{Metode Penelitian}

Penelitian ini merupakan jenis penelitian dan pengembangan (Research and Development). Model yang digunakan untuk dasar pengembangan media pembelajaran berbantuan komputer ini merupakan hasil adaptasi dari pengembangan perangkat model 4-D (four-D model) yang dikemukakan oleh Thiagarajan (1974, p.5).

Prosedur dalam penelitian ini mengadaptasi pada pengembangan model 4-D (four-D model) yang dikemukakan oleh Thiagarajan. Model ini terdiri atas 4 tahap, yaitu: define, design, develop and disseminate. Tahap pertama adalah tahap define (pendefinisian), tahap ini bertujuan untuk menetapkan dan mendefinisikan syarat-syarat pembelajaran. Ada lima langkah dalam tahap ini, yaitu: prapenelitian, analisis siswa, analisis tugas, analisis konsep, dan perumusan tujuan pembelajaran. Tahap kedua yaitu design atau perancangan. Tahap ini terdiri dari pemilihan format dan desain awal media. Desain awal media meliputi mengumpulkan bahan-bahan untuk membuat media, membuat flowchart, membuat storyboard, dan memasukkan bahan atau materi ke program Lectora. Tahap ketiga adalah tahap develop (pengembangan), yang bertujuan untuk menghasilkan media pembelajaran yang sudah direvisi berdasar masukan dari para ahli. Ada tiga langkah dalam tahapan ini, yaitu: validasi perangkat diikuti dengan revisi, uji coba terbatas, dan uji coba lapangan. Dan tahap 
keempat adalah disseminate (penyebaran), pada penelitian ini penyebaran hanya terbatas pada SMA Negeri I Girimulyo.

Desain uji coba produk dalam penelitian pengembangan ini meliputi: desain uji coba, subjek uji coba, jenis data, instrumen pengumpulan data, dan teknis analisis data. Uji coba produk dibagi menjadi dua tahapan, yaitu uji coba terbatas dan uji coba lapangan. Uji coba terbatas bertujuan untuk mengetahui tanggapan/ respon peserta didik terhadap media pembelajaran biologi berbantuan komputer materi Bryophythe. Uji coba lapangan bertujuan untuk mengetahui tingkat kelayakan proses pelaksanaan media dan dampak kemajuan yang diperoleh sebagai hasil dari pelaksanaan media pembelajaran. Uji coba lapangan menggunakan desain Nonequivalent Control-Group Design (Sugiyono, 2013, p. 116).

Subjek penelitian untuk uji coba produk yang dikembangkan adalah peserta didik kelas X SMA Negeri I Girimulyo Semester 2 Tahun Ajaran 2012/2013. Uji coba terbatas dilakukan kepada sembilan peserta didik kelas $X_{C}$ SMA Negeri I Girimulyo, yang terdiri dari 3 peserta didik yang memiliki kemampuan tinggi, 3 peserta didik yang memiliki kemampuan sedang, dan 3 peserta didik dengan kemampuan rendah. Subjek uji coba lapangan adalah kelas $X_{A}$ dan $X_{B}$ dengan jumlah peserta didik masing-masing kelas 19 orang.

Instrumen yang digunakan untuk mengumpulkan data terdiri dari lembar validasi, angket, soal dan lembar observasi. Lembar validasi digunakan untuk memvalidasi dan mengevaluasi kualitas produk yang dikembangkan baik dari aspek materi pembelajaran, aspek tampilan media, dan aspek interaksi dengan media. Angket digunakan untuk memperoleh data respon peserta didik terhadap media pembelajaran biologi berbantuan komputer dan data kemandirian belajar. Soal tes penguasaan konsep terdiri dari 20 butir soal pilihan ganda. Instrumen soal tes ini selain divalidasi dengan expert judgement juga divalidasi dengan validasi empirik. Validitas em- pirik menggunakan program QUEST. Lembar observasi digunakan untuk mengamati keterlaksanaan pembelajaran biologi yang tertuang dalam RPP dengan pembelajaran sebenarnya pada uji coba lapangan. Lembar observasi ini divalidasi oleh ahli (expert judgment).

Teknik analisis data keterlaksanaan pembelajaran dengan cara data yang diperoleh dari lembar observasi dihitung nilainya untuk setiap komponen pada setiap pertemuan. Skala persentase untuk menentukan keterlaksanaan pembelajaran menggunakan rumus sebagai berikut.

\section{\%keterlaksanaan

$$
=\frac{\text { Banyaknya deskriptor yang terlaksana }}{\text { Banyaknya deskriptor }} \times 100 \%
$$

Teknik analisis data kelayakan produk dan respon siswa terhadap produk dengan cara mengubah data yang berupa skor menjadi data kualitatif (data interval) dengan skala empat. Acuan pengubahan skor menjadi skala empat menurut Direktorat Pembinaan SMA (2010, p.60) dapat dilihat pada Tabel 1.

Tabel 1. Konversi Skor ke Nilai Skala Empat

\begin{tabular}{lc}
\hline Rentang Skor & Kriteria \\
\hline Mi+1,5 SDi $\leq \bar{M} \leq \mathrm{Mi}+3,0$ SDi & Amat Baik \\
Mi+0 SDi $\leq \bar{M}<\mathrm{Mi}+1,5 \mathrm{SDi}$ & Baik \\
Mi-1,5 SDi $\leq \bar{M}<\mathrm{Mi}+0$ SDi & Cukup \\
Mi-3 SDi $\leq \bar{M}<$ Mi-1,5 SDi & Kurang \\
\hline
\end{tabular}

Keterangan:

$\mathrm{Mi}$

Mean ideal

$1 / 2$ (skor maks+skor min)

SDi

Standar Deviasi ideal

$\bar{M}$ $1 / 6$ (skor maks-skor min)

Skor maks ideal : $\quad \Sigma$ butir kriteria $x$ skor tertinggi Skor min ideal : $\quad \Sigma$ butir kriteria $\mathrm{x}$ skor terendah

Nilai kelayakan media pembelajaran ditentukan dengan nilai minimum " $\mathrm{C}$ " dengan kategori cukup.

Teknik analisis data kemandirian belajar menggunakan teknik normalized 
gain atau sering disebut gain score yang disimbolkan dengan $<\mathrm{g}>$. Nilai $<\mathrm{g}>$ dapat dihitung dengan menggunakan rumus yang diadapatasi dari Hake (1998, p.3), yaitu:

$$
<g>=\frac{\text { SAakhir } \%-\text { SAawal } \%}{100-\text { SAawal } \%}
$$

Keterangan:

$<\mathrm{g}>\quad$ : Nilai gain score

Skor angket akhir\% : Persentase nilai angket akhir

Skor angket awal\% : Persentase nilai angket awal

Ada tiga kategori hasil analisis gain score. Kategori tersebut dapat dilihat pada Tabel 2.

Tabel 2. Kategori Hasil Analisis Menggunakan Gain Score

\begin{tabular}{cc}
\hline Nilai & Kategori \\
\hline$(<\mathrm{g}>)>0,7$ & Tinggi \\
$0,3>(<\mathrm{g}>)>0,7$ & Sedang \\
$(<\mathrm{g}>)<0,3$ & Rendah \\
\hline & $($ Sumber: Hake, 1998: 3$)$
\end{tabular}

Data peningkatan penguasaan konsep peserta didik dipeoleh melalui pretes dan postes. Data kemudian dianalisis dengan menggunakan teknik normalized gain score atau normalisasi skor gain $<\mathrm{g}>$. Dengan mengetahui rata-rata nilai $\langle$ g $>$ maka dapat diketahui peningkatan penguasaan konsep peserta didik setelah pembelajaran dengan menggunakan media berbantuan komputer. Nilai $<$ g $>$ dapat dihitung dengan menggunakan rumus berikut:

$$
<\mathrm{g}>=\frac{\text { postscore } \%-\text { prescore } \%}{100-\text { prescore } \%}
$$

Keterangan:

$\begin{array}{ll}<\mathrm{g}> & \text { : Nilai gain score } \\ \text { Postscore\% } & \text { : Persentase nilai postes } \\ \text { Prescore } \% & \text { : Persentase nilai postes }\end{array}$

Kriteria indeks $<\mathrm{g}>$ menurut Hake (1998, p.3) dapat dilihat pada Tabel 2. Analisis ketuntasan atau ketercapaian pembelajaran peserta didik diperoleh dari rumus sebagai berikut:

Tuntas $=\frac{\text { skoryangdiperoleh }}{\text { skormaksimum }} \times 100 \%$

Jika ketuntasan individu sama dengan nilai ketuntasan KKM di SMAN I Girimulyo yaitu $\geq 70$, maka peserta didik tersebut dinyatakan telah tuntas.

Untuk menguji perbedaan kemandirian belajar dan penguasaan konsep dibuat hipotesis dan untuk mengujinya digunakan statistik uji ANAKOVA. Penggunaan teknik statistik ANAKOVA memerlukan uji prasyarat yang harus dipenuhi, yaitu uji normalitas, uji homogenitas, dan uji linieritas.

\section{Hasil Penelitian dan Pembahasan}

Data hasil evaluasi produk ini meliputi data hasil evaluasi produk dari ahli materi, ahli media, pendidik biologi dan teman sejawat. Data hasil penilaian dari ahli materi terdiri dari empat aspek yaitu aspek kesesuaian materi dengan kurikulum, aspek kualitas materi pembelajaran, kualitas bahasa dan kualitas visual. Data hasil penilaian tersebut dapat dilihat pada Tabel 3. Pada aspek kesesuaian materi dengan kurikulum dan aspek kualitas visual rerata skor total adalah 12,0 dengan kategori sangat baik. Penilaian kualitas materi pembelajaran mendapat rerata skor total 27,0 dengan kategori sangat baik. Pada kualitas bahasa rerata skor total adalah 14,0 dengan kategori sangat baik. Kualitas visual di nilai sangat baik dengan rerata skor total 12,0

Tabel 3. Data Hasil Penilaian Ahli Materi

\begin{tabular}{llccc}
\hline No & \multicolumn{1}{c}{ Aspek Penilaian } & Rerata Skor Total & Rerata Skor Total (\%) & Kategori \\
\hline 1. & Kesesuaian materi dengan kurikulum & 12,0 & 100 & Sangat Baik \\
2. Kualitas materi pembelajaran & 27,0 & 96,4 & Sangat Baik \\
3. Kualitas bahasa & 14,0 & 87,5 & Sangat Baik \\
4. Kualitas visual & 12,0 & 100 & Sangat Baik \\
\hline
\end{tabular}


Data hasil penilaian dari ahli media meliputi keterbacaan teks, kualitas gambar, keserasian warna, kualitas audio, tata letak (lay out), animasi, dan interaksi dengan media. Data hasil penilaian tersebut dapat dilihat pada Tabel 4. Ahli media memberikan rerata skor 18,0 pada aspek keterbacaan teks dengan kategori baik.

Pada aspek kualitas gambar rerata skor 9,0 dengan kategori baik. Rerata skor total aspek keserasian warna adalah 12,0 dengan kategori baik. Pada aspek kualitas audio rerata skor total adalah 3,0 dengan kategori baik. Aspek tata letak mendapat rerata skor total 4,0 dan termasuk pada kategori kurang baik. Aspek animasi diberi penilaian 5,0 dengan kategori baik. Rerata skor aspek interaksi dengan media adalah 8,0 dengan kategori baik.

Data hasil penilaian dari pendidik biologi terdiri dari aspek kesesuaian materi dengan kurikulum, aspek kualitas materi pembelajaran, aspek kualitas bahasa, aspek kualitas visual, aspek keterbacaan teks, aspek kualitas gambar, aspek keserasian warna, aspek kualitas audio, aspek tata letak, aspek animasi, aspek interaksi dengan media, dan aspek kegrafikan. Data hasil penilaian tersebut disajikan pada Tabel 5.

Penilaian media dilakukan pada empat orang pendidik biologi. Rerata aspek kesesuaian materi dengan kurikulum adalah 12,0 dengan kategori sangat baik. Pada aspek kualitas materi pembelajaran rerata skor total adalah 24,75 dengan kategori sangat baik. Aspek kualitas bahasa mendapat rerata skor total 14,5 dan termasuk kategori sangat baik. Rerata aspek kualitas visual adalah 11,25 dengan kategori sangat baik. Aspek keterbacaan teks dinilai sangat baik oleh pendidik biologi dengan nilai rerata adalah 20,5. Pada aspek kualitas gambar mendapat rerata 10,75 dengan kategori sangat baik. Aspek keserasian warna termasuk dalam kategori sangat baik dengan nilai rerata 14,25 . Aspek kualitas audio mendapat rerata 3,75 dan terma- suk dalam kategori sangat baik. Rerata aspek tata letak adalah 7,0 dengan kategori sangat baik. Aspek animasi dinilai baik oleh pendidik biologi dan mendapat rerata sebesar 6,25. Pada aspek interaksi dengan media mendapat rerata 10,0 dengan kategori sangat baik. Rerata aspek kegrafikan adalah 7,5 dengan kategori sangat baik.

Data hasil penilaian dari teman sejawat terdiri dari aspek kesesuaian materi dengan kurikulum, aspek kualitas materi pembelajaran, aspek kualitas bahasa, aspek kualitas visual, aspek keterbacaan teks, aspek kualitas gambar, aspek keserasian warna, aspek kualitas audio, aspek tata letak, aspek animasi, aspek interaksi dengan media, dan aspek kegrafikan. Data hasil penilaian tersebut dapat dilihat pada Tabel 6.

Berdasarkan penilaian yang telah dilakukan oleh 4 teman sejawat seperti yang digambarkan pada Tabel 6, pada aspek kesesuaian materi dengan kurikulum mendapat rerata 12,0 dengan kategori sangat baik. Pada aspek kualitas materi pembelajaran rerata skor total adalah 25,25 dengan kategori sangat baik. Aspek kualitas bahasa mendapat rerata skor total 15,25 dan termasuk kategori sangat baik. Rerata aspek kualitas visual adalah 11,25 dengan kategori sangat baik. Aspek keterbacaan teks dinilai sangat baik oleh pendidik biologi dengan nilai rerata adalah 21,25. Pada aspek kualitas gambar mendapat rerata 11,25 dengan kategori sangat baik. Aspek keserasian warna termasuk dalam kategori baik dengan nilai rerata 12,75. Aspek kualitas audio mendapat rerata 3,5 dan termasuk dalam kategori sangat baik. Rerata aspek tata letak adalah 6,5 dengan kategori sangat baik. Aspek animasi dinilai baik oleh pendidik biologi dan mendapat rerata sebesar 7,25. Pada aspek interaksi dengan media mendapat rerata 10,5 dengan kategori sangat baik. Rerata aspek kegrafikan adalah 7,75 dengan kategori sangat baik. 
Tabel 4. Data Hasil Penilaian Ahli Media

\begin{tabular}{clccc}
\hline No & Aspek Penilaian & Rerata Skor Total & Rerata Skor Total (\%) & Kategori \\
\hline 1. & Keterbacaan teks & 18,0 & 75 & Baik \\
2. & Kualitas gambar & 9,0 & 75 & Baik \\
3. & Keserasian warna & 12,0 & 75 & Baik \\
4. & Kualitas audio & 3,0 & 75 & Baik \\
5. & Tata letak (lay out) & 4,0 & 50 & Kurang baik \\
6. & Animasi & 5,0 & 62,5 & Baik \\
7. & Interaksi dengan media & 8,0 & 66,6 & Baik \\
\hline
\end{tabular}

Tabel 5. Data Hasil Penilaian Pendidik Biologi

\begin{tabular}{clccc}
\hline No & \multicolumn{1}{c}{ Aspek Penilaian } & $\begin{array}{c}\text { Rerata Skor } \\
\text { Total }\end{array}$ & $\begin{array}{c}\text { Rerata Skor } \\
\text { Total }(\%)\end{array}$ & Kategori \\
\hline 1. & Kesesuaian materi dengan kurikulum & 12,0 & 100 & Sangat Baik \\
2. & Kualitas materi pembelajaran & 24,75 & 88,4 & Sangat Baik \\
3. & Kualitas bahasa & 14,5 & 90,6 & Sangat Baik \\
4. & Kualitas visual & 11,25 & 93,8 & Sangat Baik \\
5. & Keterbacaan teks & 20,5 & 85,4 & Sangat Baik \\
6. & Kualitas gambar & 10,75 & 89,6 & Sangat Baik \\
7. & Keserasian warna & 14,25 & 89,1 & Sangat Baik \\
8. & Kualitas audio & 3,75 & 93,7 & Sangat Baik \\
9. & Tata letak (lay out) & 7,0 & 87,5 & Sangat Baik \\
10. & Animasi & 6,25 & 78,1 & Baik \\
11. & Interaksi dengan media & 10,0 & 83,3 & Sangat Baik \\
12. & Kegrafikan & 7,5 & 93,8 & Sangat Baik \\
\hline
\end{tabular}

Tabel 6. Data Hasil Penilaian Teman Sejawat

\begin{tabular}{clccc}
\hline No & \multicolumn{1}{c}{ Aspek Penilaian } & $\begin{array}{c}\text { Rerata Skor } \\
\text { Total }\end{array}$ & $\begin{array}{c}\text { RerataSkor } \\
\text { Total }(\%)\end{array}$ & Kategori \\
\hline 1. & Kesesuaian materi dengan kurikulum & 12,0 & 100 & Sangat Baik \\
2. & Kualitas materi pembelajaran & 25,25 & 90,17 & Sangat Baik \\
3. & Kualitas bahasa & 15,25 & 95,3 & Sangat Baik \\
4. & Kualitas visual & 11,25 & 93,7 & Sangat Baik \\
5. & Keterbacaan teks & 21,25 & 88,5 & Sangat Baik \\
6. & Kualitas gambar & 11,25 & 93,7 & Sangat Baik \\
7. & Keserasian warna & 12,75 & 79,6 & Baik \\
8. & Kualitas audio & 3,5 & 87,5 & Sangat Baik \\
9. & Tata letak (lay out $)$ & 6,5 & 81,2 & Sangat Baik \\
10. & Animasi & 7,25 & 90,6 & Sangat Baik \\
11. & Interaksi dengan media & 10,5 & 87,5 & Sangat Baik \\
12. & Kegrafikan & 7,75 & 96,8 & Sangat Baik \\
\hline
\end{tabular}

Media pembelajaran biologi berbantuan komputer yang telah dievaluasi oleh ahli media, ahli materi, pendidik biologi, dan teman sejawat kemudian digunakan untuk uji coba terbatas. Uji coba terbatas dilakukan pada 9 orang peserta didik kelas $X_{C}$ SMA Negeri I Girimulyo. Data dari kegiatan pembelajaran pada uji coba terbatas terdiri dari data respon peserta didik. Respon peserta didik selama pem- belajaran dengan menggunakan media pembelajaran biologi berbantuan komputer dapat diketahui dari angket yang disebarkan peneliti pada akhir pembelajaran. Data hasil respon peserta didik meliputi aspek kualitas materi, kualitas bahasa, kualitas visual, keterbacaan teks, keserasian warna, tata letak (lay out), interaksi dengan media, dan kemandirian pada uji coba terbatas secara ringkas disajikan pada Tabel 7. 
Berdasarkan data pada Tabel 7, dapat diketahui pada aspek kualitas materi mendapat rerata skor 14,4 dan termasuk kategori sangat baik. Aspek kualitas bahasa termasuk dalam kategori sangat baik dengan nilai rerata 13,8 . Rerata aspek kualitas visual adalah 10,4 dengan kategori sangat baik. Pada aspek keterbacaan teks mendapat rerata skor 9,8 dengan kategori sangat baik. Aspek keserasian warna dinilai baik oleh teman sejawat dengan rerata skor 6,5. Rerata aspek tata letak adalah 7,4 dengan kategori sangat baik. Aspek interaksi dengan media mendapat rerata skor 7,0 dengan kategori sangat baik.

Uji coba lapangan dilakukan pada kelas $X_{A}$ dan $X_{B}$ dengan jumlah peserta didik masing-masing kelas adalah 19 orang. Respon peserta didik meliputi aspek kua- litas materi, kualitas bahasa, kualitas visual, keterbacaan teks, keserasian warna, tata letak, interaksi dengan media, dan kemandirian. Data hasil respon peserta didik berupa skor dikonversikan menjadi skala empat. Data hasil respon peserta didik pada uji coba lapangan secara ringkas disajikan pada Tabel 8.

Data kemandirian belajar peserta didik diperoleh melalui lembar angket yang disebarkan pada awal dan akhir pembelajaran. Lembar angket berdasarkan lima aspek yaitu ketidaktergantungan pada orang lain, percaya diri, disiplin, tanggung jawab, serta inisiatif. Data yang diperoleh dari angket kemandirian dianalisis menggunakan gain score. Hasil perhitungan angket kemandirian belajar menggunakan gain score $(<\mathrm{g}>)$ dapat dilihat pada Tabel 9.

Tabel 7. Data Hasil Respon Peserta Didik Uji Coba Terbatas

\begin{tabular}{clccc}
\hline No & Aspek Penilaian & Rerata Skor Total & Rerata Skor Total (\%) & Kategori \\
\hline 1. & Kualitas Materi & 14,4 & 90 & Sangat Baik \\
2. & Kualitas Bahasa & 13,8 & 86,25 & Sangat Baik \\
3. & Kualitas Visual & 10,4 & 86,6 & Sangat Baik \\
4. & Keterbacaan Teks & 9,8 & 81,6 & Sangat Baik \\
4. & Keserasian Warna & 6,5 & 81,25 & Baik \\
5. & Tata Letak & 7,4 & 92,5 & Sangat Baik \\
6. & Interaksi dengan Media & 7,0 & 87,5 & Sangat Baik \\
\hline
\end{tabular}

Tabel 8. Data Hasil Respon Peserta Didik Uji Coba Lapangan

\begin{tabular}{clccc}
\hline No & Aspek Penilaian & Rerata Skor Total & Rerata Skor Total (\%) & Kategori \\
\hline 1. & Kualitas Materi & 13,95 & $87 \%$ & Sangat Baik \\
2. & Kualitas Bahasa & 13,35 & $83 \%$ & Sangat Baik \\
3. & Kualitas Visual & 10,05 & $83 \%$ & Sangat Baik \\
4. & Keterbacaan Teks & 9,57 & $79 \%$ & Baik \\
4. & Keserasian Warna & 6,5 & $81 \%$ & Baik \\
5. & Tata Letak & 6,67 & $83 \%$ & Sangat Baik \\
6. & Interaksi dengan Media & 6,9 & $86 \%$ & Sangat Baik \\
\hline
\end{tabular}

Tabel 9. Ringkasan Data Angket Kemandirian Peserta Didik pada Uji Coba Lapangan

\begin{tabular}{lcccccc}
\hline & \multicolumn{3}{c}{ Kelas Kontrol (KK) } & \multicolumn{2}{c}{ Kelas Treament (KT) } \\
\cline { 2 - 7 } & Sebelum & Sesudah & $\begin{array}{c}\text { Gain Score/ } \\
\text { Kriteria }\end{array}$ & Sebelum & Sesudah & $\begin{array}{c}\text { Gain Score/ } \\
\text { Kriteria }\end{array}$ \\
\hline Nilai tertinggi & 76 & 85 & 0,24 & 76 & 93 & 0,40 \\
Nilai Terendah & 50 & 63 & $/$ Rendah & 55 & 63 & /Sedang \\
Rerata & 58 & 66,26 & 65,6 & 80,2 & \\
\hline
\end{tabular}


Tabel 10. Ringkasan Data Nilai Penguasaan Konsep Peserta Didik pada Uji Coba Lapangan

\begin{tabular}{|c|c|c|c|c|c|c|}
\hline & \multicolumn{3}{|c|}{ Kelas Kontrol (KK) } & \multicolumn{3}{|c|}{ Kelas Treatment $(\mathrm{KT})$} \\
\hline & Pretes & Posttes & $\begin{array}{c}\text { Gain Score } \\
\text { /Kriteria }\end{array}$ & Pretes & postes & $\begin{array}{l}\text { Gain Score } \\
\text { /Kriteria }\end{array}$ \\
\hline Nilai tertinggi & 65 & 85 & \multirow{3}{*}{$\begin{array}{c}0,55 \\
\text { (Sedang) }\end{array}$} & 65 & 100 & \multirow{3}{*}{$\begin{array}{c}0,65 \\
\text { (sedang) }\end{array}$} \\
\hline Nilai Terendah & 215 & 50 & & 25 & 45 & \\
\hline Rerata & 38,5 & 70,5 & & 42,1 & 79,7 & \\
\hline
\end{tabular}

Berdasarkan data Tabel 9, dapat dapat diketahui kemandirian belajar yang diukur sebelum pembelajaran nilai tertinggi diperoleh peserta didik pada KT dan KK yaitu 76, sedangkan nilai terendah diperoleh oleh peserta didik KK yaitu 50 . Rerata kemandirian belajar sebelum pembelajaran adalah 58 untuk KK dan 65,6 untuk KT. Nilai tertinggi setelah pembelajaran menggunakan media pembelajaran berbantuan komputer diperoleh KT yaitu 93, sedangkan nilai terendah diperoleh peserta didik KK yaitu 55. Rerata kemandirian belajar setelah pembelajaran adalah 66,26 untuk KK dan 80,2 untuk KT.Nilai gain score KT lebih tinggi daripada KK, yaitu 0,40 untuk KT dan 0,24 untuk KK. Jadi, dari perbandingan gain score antara dua kelas penelitian dapat diketahui adanya peningkatan kemandirian pada kelas treatment (KT).

Hasil penguasaan konsep peserta didik diperoleh melalui tes hasil belajar yang diberikan kepada peserta didik pada awal pembelajaran (pretest) dan akhir pembelajaran (posttest). Hasil pengukuran kemampuan penguasaan konsep yang dilakukan memperoleh hasil yang ditabulasikan pada Tabel 10.

Berdasarkan data pada Tabel 10, terlihat perbedaan penguasaan konsep antara kelas kontrol (KK) dan kelas treatment $(\mathrm{KT})$. Rerata nilai pretes kedua kelas yaitu 38,5 untuk KK dan 42,1 untuk KT. Nilai tertinggi diperoleh oleh peserta didik KK dan KT yaitu 65. Nilai terendah untuk KK adalah 15, sedangkan KT yaitu 25. Rerata nilai postes antara KK dan KT berbeda yaitu 70,5 untuk kelas KK dan 79,7 untuk kelas KT. Nilai tertinggi diperoleh oleh kelas KT yaitu 100, sedangkan KK sebesar 85. Nilai terendah untuk KT adalah
45, sedangkan untuk KK sebesar 50. Nilai gain score KT lebih tinggi daripada KK, yaitu 0,65 untuk KT dan 0,55 untuk KK. Jadi, dari perbandingan gain score antara dua kelas penelitian dapat diketahui adanya peningkatan penguasaan konsep pada kelas treatment (KT). Untuk menge-ahui tingkat ketuntasan penguasaan konsep dapat dilihat pada Tabel 11.

Tabel 11. Ketuntasan Penguasaan Konsep Peserta Didik pada Uji Coba Lapangan

\begin{tabular}{llcc}
\hline \multirow{2}{*}{ No } & \multirow{2}{*}{ Kriteria } & \multicolumn{2}{c}{ Jumlah Peserta } \\
\cline { 3 - 4 } & & KK & KT \\
\hline & & 10 & 16 \\
1. & Tuntas & 7 & 3 \\
\hline
\end{tabular}

Berdasarkan data pada Tabel 11, diketahui jumlah peserta didik yang tuntas yaitu 16 peserta didik untuk kelas treatment dan 10 peserta didik untuk kelas kontrol, sedangkan yang tidak tuntas berjumlah 3 peserta didik untuk kelas KT dan 7 peserta didik untuk kelas KK.

Untuk melihat perbedaan kemandirian belajar kelas kontrol dan kelas treatment dilakukan uji ANAKOVA. Sebelum pengujian hipotesis dilaksanakan terlebih dahulu dilakukan pengujian prasyarat analisis yang meliputi uji normalitas, uji homogenitas, dan uji linieritas.

Apabila keseluruhan uji prasyarat telah terpenuhi, maka analisis untuk pengujian hipotesis dengan uji ANAKOVA dapat dilaksanakan. Uji normalitas dilakukan dengan tujuan untuk mengetahui apakah sebaran data yang dianalisis berdistribusi normal atau tidak. Hasil uji normalitas yang dilakukan dapat dilihat pada Tabel 12. 
Tabel 12. Hasil Uji Normalitas

\begin{tabular}{cccc}
\hline Data & Kelas & Sig. & Keterangan \\
\hline \multirow{2}{*}{ Pretes } & Kontrol & 0,200 & Normal \\
& Treatment & 0,120 & Normal \\
\hline \multirow{2}{*}{ Postes } & Kontrol & 0,065 & Normal \\
& Treatment & 0,501 & Normal \\
\hline
\end{tabular}

Berdasarkan Tabel 12 dapat diketahui bahwa nilai Sig. data angket kemandirian belajar baik kelas treatment maupun kelas kontrol terdistribusi normal karena nilai sig $>0,05$.

Uji homogenitas bertujuan untuk mengetahui apakan sampel berasal dari populasi yang homogen atau tidak. Analisis yang digunakan adalah uji $\mathrm{F}$ yang dihitung dengan menggunakan program SPSS 18.0, yang disajikan pada Tabel 13.

Berdasarkan Tabel 13 dapat diketahui data angket kemandirian memiliki nilai Sig. $>0,05$, sehingga dapat disimpulkan data angket kemandirian balajar memiliki varians yang sama atau homogen.

Untuk mengetahui apakah dua variabel yang akan dikenai prosedur analisis statistik korelasional menunjukkan hubungan yang linier atau tidak, maka dilakukan uji linieritas dengan menggunakan program SPSS versi 18,0. Secara singkat hasil perhitungan disajikan pada Tabel 14 .

Berdasarkan hasil uji linieritas pada Tabel 14, dapat diketahui nilai Sig. pada linearity adalah 0,033. Karena nilai Sig. < 0,05 maka dapat disimpulkan hubungan antara kemandirian belajar dengan penguasaan konsep linier.

Untuk mengetahui ada tidaknya perbedaan kemandirian peserta didik antara kelas treatment dan kelas kontrol maka dilakukan perhitungan dengan menggunakan uji statistik ANAKOVA dengan menggunakan program SPSS 18,0. Secara singkat hasil perhitungan disajikan pada Tabel 15.

Tabel 13. Hasil Uji Homogenitas

\begin{tabular}{clcccc}
\hline Nilai & \multicolumn{1}{c}{ Data } & df1 & df2 & Sig & Ket \\
\hline \multirow{3}{*}{ Pretes } & Based on Mean & 1 & 34 & 0,419 & Homogen \\
& Based on Median & 1 & 34 & 0,550 & Homogen \\
& Based on Median and with adjusted df & 1 & 34 & 0,550 & Homogen \\
& Based on trimmed mean & 1 & 34 & 0,419 & Homogen \\
\hline \multirow{5}{*}{ Postest } & Based on Mean & 1 & 34 & 0,859 & Homogen \\
& Based on Median & 1 & 34 & 0,924 & Homogen \\
& Based on Median and with adjusted df & 1 & 34 & 0,924 & Homogen \\
& Based on trimmed mean & 1 & 34 & 0,879 & Homogen \\
\hline
\end{tabular}

Tabel 14.Hasil Uji Linieritas

\begin{tabular}{lccccc}
\hline & Sum of Squares & df & Mean Square & F & Sig. \\
\hline Linearity & 539,597 & 1 & 539,597 & 5,192 & 0,033 \\
\hline
\end{tabular}

Tabel 15. Uji Perbedaan Kemandirian Peserta Didik

\begin{tabular}{lccccc}
\hline Data & df & Mean Square & F & Sig. & Ket \\
\hline Corrected Model & 2 & 213,902 & 3,562 & 0,040 & Ho diterima \\
Intercept & 1 & 1381,334 & 23,001 & 0,000 & \\
Pretest & 1 & 111,106 & 1,850 & 0,183 & \\
Kelas & 1 & 334,818 & 5,575 & 0,024 & \\
\hline
\end{tabular}


Berdasarkan Tabel 15, diketahui bahwa nilai Sig. adalah 0,183. Nilai Sig. > 0,05, yang artinya $\mathrm{H}_{0}$ diterima. Kesimpulannya adalah setelah dikendalikan oleh kovariabel pretes, tidak terdapat perbedaan penguasaan konsep peserta didik yang menggunakan media pembelajaran berbantuan komputer dengan peserta didik tanpa menggunakan media pembelajaran berbantuan komputer. Oleh karena itu, perlu dilanjutkan dengan uji lanjut yaitu uji-t. Hasil perhitungan disajikan pada Tabel 16.

Berdasarkan Tabel 16, dapat diketahui bahwa nilai Sig. < 0,05. Hal ini dapat diartikan bahwa terdapat perbedaan kemandirian belajar yang signifikan antara peserta didik yang menggunakan media pembelajaran berbantuan komputer dengan peserta didik tanpa menggunakan media pembelajaran berbantuan komputer.

Untuk melihat perbedaan penguasaan konsep kelas kontrol dan kelas treatment dilakukan uji ANAKOVA. Sebelum pengujian hipotesis dilaksanakan terlebih dahulu dilakukan pengujian prasyarat analisis yang meliputi uji normalitas, uji homogenitas, dan uji linieritas.

Apabila keseluruhan uji prasyarat telah terpenuhi, maka analisis untuk pengujian hipotesis dengan uji ANAKOVA dapat dilaksanakan. Uji normalitas dilakukan dengan tujuan untuk mengetahui apakah sebaran data yang dianalisis berdistribusi normal atau tidak. Hasil uji normalitas disajikan pada Tabel 17. Pengujian dilakukan pada nilai posttes dan analisis statistik yang digunakan pada penelitian ini adalah dengan menggunakan uji KolmogorofSmirnof satu sampel yang dihitung dengan menggunakan program SPSS 18.0.

Tabel 17 menunjukkan bahwa data pretes dan posttes memiliki probabilitas Sig. $>0,05$, sehingga dapat disimpulkan data terdistribusi normal. Uji homogenitas bertujuan untuk mengetahui apakah sampel berasal dari populasi yang homogen atau tidak. Analisis statistik yang digunakan pada penelitian ini menggunakan uji $\mathrm{F}$ yang diselesaikan dengan program SPSS 18.0, yang ditunjukkan pada Tabel 18.

Tabel 16. Hasil Uji Hipotesis

\begin{tabular}{cccc}
\hline Data & \multicolumn{3}{c}{ Independent Samples Test } \\
\cline { 2 - 4 } & $\mathrm{t}$ & $\mathrm{df}$ & Sig. (2-tailed) \\
\hline Equal variances assumed & $-2,268$ & 34 & 0,030 \\
Equal variances not assumed & $-2,267$ & 33,515 & 0,030 \\
\hline
\end{tabular}

Tabel 17.Hasil Uji Normalitas

\begin{tabular}{cccc}
\hline Data & Kelas & Probabilitas & Keterangan \\
\hline Pretes & Kontrol & 0,200 & Normal \\
& Treatment & 0,120 & Normal \\
\hline Postes & Kontrol & 0,200 & Normal \\
& Treatment & 0,115 & Normal \\
\hline
\end{tabular}

Tabel 18. Hasil Uji Homogenitas

\begin{tabular}{clcccc}
\hline Nilai & \multicolumn{1}{c}{ Data } & df1 & df2 & Sig & Ket \\
\hline Pretes & Based on Mean & 1 & 34 & 0,419 & Homogen \\
& Based on Median & 1 & 34 & 0,550 & Homogen \\
& Based on Median and with adjusted df & 1 & 34 & 0,550 & Homogen \\
& Based on trimmed mean & 1 & 34 & 0,4191 & Homogen \\
\hline Postest & Based on Mean & 1 & 34 & 0,844 & Homogen \\
& Based on Median & 1 & 34 & 0,881 & Homogen \\
& Based on Median and with adjusted df & 1 & 34 & 0,881 & Homogen \\
\cline { 2 - 6 } & Based on trimmed mean & 1 & 34 & 0,809 & Homogen \\
\hline
\end{tabular}


Tabel 19. Hasil Uji Linieritas

\begin{tabular}{lccccc}
\hline & Sum of Squares & df & Mean Square & F & Sig. \\
\hline Linearity & 539,597 & 1 & 539,597 & 5,192 & 0,033 \\
\hline
\end{tabular}

Tabel 20.Uji Perbedaan Penguasaan Konsep Peserta Didik

\begin{tabular}{lccccc}
\hline Data & df & $\begin{array}{c}\text { Mean } \\
\text { Square }\end{array}$ & F & Sig & Keterangan \\
\hline Corrected Model & 2 & 1055,826 & 12,360 & 0,000 & Ho ditolak \\
Intercept & 1 & 9532,847 & 111,598 & 0,000 & \\
Pretest & 1 & 1027,846 & 12,033 & 0,001 & \\
Kelas & 1 & 576,875 & 6,753 & 0,014 & \\
\hline
\end{tabular}

Berdasarkan Tabel 18, dapat diketahui data angket kemandirian belajar memiliki Sig. > 0,05, sehingga dapat disimpulkan data angket kemandirian belajar memiliki varians yang sama atau homogen.

Untuk mengetahui apakah dua variabel yang akan dikenai prosedur analisis statistik korelasional menunjukkan hubungan yang linier atau tidak, maka dilakukan uji linieritas dengan menggunakan program SPSS versi 18,0. Secara singkat hasil perhitungan disajikan pada Tabel 19.

Berdasarkan hasil uji linieritas pada Tabel 24, dapat diketahui nilai Sig. pada linearity adalah 0,033. Karena nilai Sig. < 0,05 maka dapat disimpulkan hubungan antara kemandirian belajar dengan penguasaan konsep linier.

Untuk mengetahui ada tidaknya perbedaan ketercapaian penguasaan konsep antara kelas treatment dan kelas kontrol maka dilakukan perhitungan dengan menggunakan uji statistik ANAKOVA dengan menggunakan program SPSS 18.0. Secara singkat hasil perhitungan dapat dilihat pada Tabel 20.

Berdasarkan Tabel 20, dapat diketahui bahwa nilai Sig. untuk ketercapaian penguasaan konsep peserta didik adalah 0,019 . Berdasarkan data di atas karena Sig. (2-tailed) $<0,05$ yaitu 0,019 < 0,05 maka $\mathrm{H}_{0}$ ditolak dan Ha diterima. Hal ini dapat diartikan bahwa setelah dikendalikan oleh kovariabel pretes, ada perbedaan penguasaan konsep peserta didik yang menggunakan media pembelajaran berbantuan komputer dengan peserta didik tanpa menggunakan media pembelajaran berbantuan komputer.

\section{Simpulan dan Saran}

Simpulan

Berdasarkan hasil analisis data dan pembahasan yang telah dilakukan, maka dapat ditarik kesimpulan sebagai berikut.

Secara umum kualitas media pembelajaran biologi berbantuan komputer yang dihasilkan sudah termasuk dalam kategori "baik", ini terlihat dari hasil evaluasi ahli materi, ahli media, pendidik biologi, teman sejawat, respon/tanggapan peserta didik pada uji coba terbatas dan respon/tanggapan peserta didik pada uji coba lapangan terhadap media pembelajaran biologi berbantuan komputer. Dengan demikian, produk pengembangan media pembelajaran biologi berbantuan komputer yang telah dikembangkan sudah layak dipergunakan dalam proses pembelajaran.

Media pembelajaran biologi yang dihasilkan efektif meningkatkan kemandirian belajar peserta didik dan meningkatkan penguasaan konsep peserta didik. Hal ini ditunjukkan dengan adanya perbedaan hasil kemandirian belajar dan penguasaan konsep yang diperoleh antara kelas kontrol dan kelas treatment.

\section{Saran}

Berdasarkan hasil penelitian yang sudah disajikan dapat disarankan hal-hal 
sebagai berikut. Pertama, program media pembelajaran berbantuan komputer ini efektif dapat meningkatkan kemandirian dan penguasaan konsep peserta didik, sehingga diharapkan pendidik dapat menggunakan media pembelajaran ini dalam kegiatan belajar mengajar. Kedua, media pembelajaran biologi berbantuan komputer ini diharapkan dapat disebarluaskan (disseminate) ke Sekolah Menengah Atas (SMA) atau Madrasah Aliyah Negeri (MAN) lainnya untuk mengetahui kelayakan produk secara umum.

Media yang dikembangkan hanya terbatas pada materi tumbuhan lumut sehingga diharapkan guru dapat membuat media pembelajaran lain yang menyajikan materi-materi biologi yang bersifat abstrak.

\section{Daftar Pustaka}

Direktorat Pembinaan SMA. (2010). Juknis penyusunan perangkat penilaian afektif di SMA. Diambil pada tanggal 10 Oktober 2012 dari (http://docs.google.com/viewer?a $=\mathrm{v} \& \mathrm{q}=$ =ache:Kckp86jVEtcJ:www.gu ruindonesia.net/admin/file/f__8899
_22.JuknisPengembanganBahanAja r.pdf).

Hake, R. R. (1998). Interactive-engagement vs traditional methods: A sixthousandstudent survey of mechanicstest data for introductory phsyics course. The American Journal of Physics Research 66, 64-74.

Hamalik, O. (2005). Metodebelajar dan kesulitan-kesulitan belajar. Bandung: Tarsito.

Thiagarajan, S; Semmel, D.S; \& Semmel, M.I. (1974). Instructional Development for Training Teachers of exceptional children: Bloomington Indiana: Indiana University

Sugiyono. (2013). Metode penelitian pendidikan: pendekatan kuantitatif, kualitatif, dan rEd. Bandung: Alfabeta.

Wagiran. (2008). Pengembangan media pembelajaran berbantuan komputer dalam mendukung perkuliahan metrologi. Jurnal Kependidikan, 38, 225-242.

Yamin, M. (2007). Desain pembelajaran berbasis tingkat satuan pendidikan. Jakarta: Gaung Persada Press. 